\section{Phylogeny of Pakistani Cattle Breeds using Mitochondrial Cytochrome b Gene}

\author{
Tanveer Hussain ${ }^{1, *}$, Masroor Ellahi Babar ${ }^{1}$, Marcos De Donato $^{2}$, Abdul Wajid ${ }^{1}$, \\ Asif Nadeem ${ }^{3}$, Zahoor Ahmad ${ }^{3}$, Waqas Ahmad Khan ${ }^{4}$, Sunday O. Peters ${ }^{5}$ and \\ Ikhide G. Imumorin ${ }^{6}$ \\ ${ }^{1}$ Department of Molecular Biology, Virtual University of Pakistan, Lahore \\ ${ }^{2}$ Tecnologico de Monterrey, Campus Queretaro, Department of Bioengineering, \\ Queretaro, Mexico \\ ${ }^{3}$ Institute of Biochemistry and Biotechnology, University of Veterinary and Animal \\ Sciences, Lahore \\ ${ }^{4}$ Department of Biotechnology, University of Sargodha, Sargodha \\ ${ }^{5}$ Department of Animal Sciences, Berry College, Mount Berry, Georgia, USA \\ ${ }^{6}$ School of Biological Sciences, Georgia Institute of Technology, Atlanta, Georgia, USA
}

\begin{abstract}
A B S T R A C T
Zooarchaeological data indicates that the Near East and the Indus Valley were the centers of domestication and diffusion of modern day cattle. To better understand the origin and genetic diversity of native cattle breeds (Bos indicus) in Pakistan, partial sequencing of the mitochondrial gene cytochrome b (339 bp) was done in 136 individuals from 10 different breeds. Analysis of the Cyt b gene showed high conservation in Pakistani cattle as expected, with only 26 individuals showing nucleotide changes. Only 5 point mutations were present in multiple individuals (SNP), but one was specific for indicine cattle. Two Lohani and 5 Nari Master cattle showed nucleotide changes specific to taurine cattle. Of the changes found, only three produced amino acid changes in the protein sequence. The UPGMA tree showed a clear differentiation between taurine and indicine cattle, except mitochondrial taurine sequences in Lohani and Nari Master breeds. The within-breed estimates of divergence were very low in all breeds except for Nari Master (mixed-bred). The estimates of divergence among breeds were also low for most breed pairs, except for Nari Master and Dhanni. While the overall genetic divergence within the $B$. indicus or within $B$. taurus were also very low ( 0.002 and 0.003 , respectively), however the genetic difference between $B$. indicus and $B$. taurus was significantly higher $(0.014)$.
\end{abstract}
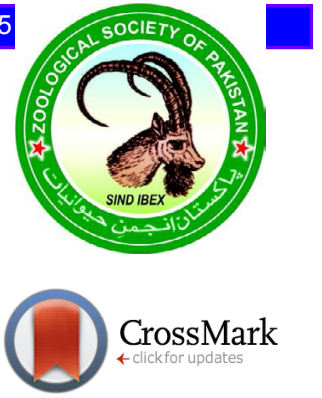

Article Information

Received 12 August 2015

Revised 24 July 2017

Accepted 18 November 2017

Available online 31 August 2018

Authors' Contribution

TH and MEB designed and planned the study. TH, MDD, AW, AN, ZA and

WAK performed the sampling and

lab work. TH, MEB, MDD, SOP and

IGI contributed to data analysis and

manuscript writing.

Key words

Pakistani Cattle, Cytochrome b,

Genetic diversity, Phylogenetics.

\section{INTRODUCTION}

$\mathrm{P}$ akistan had 44.4 million cattle in 2016-17 (GoP, 2017) with 15 distinct breeds for which very little information on genetic architecture is available. Present day domestic cattle were domesticated from the extinct aurochs, Bos primigenius (Payne, 1991; Troy et al., 2001). After the last glacial event of 15,000 years ago, B. primigenius was found throughout almost the whole of Eurasia and North Africa. The zooarchaeological data indicates the Near East and the Indus Valley (Pakistan, northwest India, and eastern Afghanistan) as domestication and diffusion centers of modern cattle (Helmer et al., 2005). The mitochondrial genome (mtDNA) of vertebrates has become a common tool for resolving phylogenetic relationships, domestication and to estimate degrees of relatedness and divergence times. The use of mtDNA relies on calibrated molecular clocks at different evolutionary depths due to its peculiar

\footnotetext{
Corresponding author: tanveer.hussain@vu.edu.pk 0030-9923/2018/0006-2029 \$ 9.00/0

Copyright 2018 Zoological Society of Pakistan
}

properties of maternal inheritance and high mutation rate which allows for the accumulation of molecular diversity within the time frame of domestic history (Carmela et al., 2000; Simon et al., 2006).

The phylogenetic information contained in cytochrome b (Cyt b) gene has been widely used for intra- and interspecies comparisons and it is considered to be a good marker to study the genetic differentiation and phylogenetic relationships among species within the same genus or the same family (Browers et al., 1994; Zardoya and Meyer, 1996), and it has been also widely used to study the origin, taxonomy and phylogeny of the Bovinae subfamily (Birungi and Arctander, 2001; Hassanin and Ropiquet, 2004). Some studies have been carried out to determine the genetic relationships and structure of some of the cattle populations in this region (Metta et al., 2004; Mukesh et al., 2004; Karthickeyan et al., 2006, 2009; Sodhi et al., 2006; Rehman and Khan, 2009; Azam et al., 2012). This study was carried out to assess the genetic differentiation and phylogeny of 10 major cattle breeds in Pakistan using the mtDNA cytochrome $b$ region. 
Table I.- The nucleotide changes in CYTB sequences of Pakistani cattle and the amino acid changes, where appropriate. Shaded changes are found typically in taurine cattle.

\begin{tabular}{|c|c|c|c|c|c|c|c|c|c|}
\hline Position & 93 & 196 & 161 & 2803 & 312 & 318 & 331 & 345 & 384 \\
\hline $\begin{array}{l}\text { Consensus } \\
\text { indicine }\end{array}$ & $\mathrm{G}$ & G & $\mathrm{T}$ & $\mathrm{T}$ & $\mathrm{T}$ & $\mathrm{T}$ & G & $\mathrm{C}$ & $\mathrm{C}$ \\
\hline $\begin{array}{l}\text { Consensus } \\
\text { taurine }\end{array}$ & A & G & $\mathrm{T}$ & $\mathrm{T}$ & $\mathrm{C}$ & $\mathrm{T}$ & G & $\mathrm{T}$ & $\mathrm{T}$ \\
\hline $\begin{array}{l}\text { Amino acid } \\
\text { change }\end{array}$ & & $\mathrm{V} \rightarrow \mathrm{I}$ & & & & & $\mathrm{E} \rightarrow \mathrm{K}$ & & \\
\hline Lohani 8 & A & & & & $\mathrm{C}$ & & & $\mathrm{T}$ & $\mathrm{T}$ \\
\hline Lohani 11 & A & & & & $\mathrm{C}$ & & & $\mathrm{T}$ & $\mathrm{T}$ \\
\hline Nari Master 3 & A & & & & & & & & \\
\hline Nari Master 4 & A & & & & $\mathrm{C}$ & & & $\mathrm{T}$ & \\
\hline Nari Master 6 & A & & & & $\mathrm{C}$ & & & $\mathrm{T}$ & $\mathrm{T}$ \\
\hline Nari Master 9 & A & & & & $\mathrm{C}$ & & & $\mathrm{T}$ & $\mathrm{T}$ \\
\hline Nari Master 11 & A & & & & $\mathrm{C}$ & & & $\mathrm{T}$ & $\mathrm{T}$ \\
\hline Nari Master 22 & A & & $\mathrm{C}$ & & $\mathrm{C}$ & & & $\mathrm{T}$ & $\mathrm{T}$ \\
\hline Dajal 20 & & A & & & & & & & \\
\hline Dahnni 1 & & & & $\mathrm{C}$ & & & & & \\
\hline Dahnni 2 & & & & $\mathrm{C}$ & & & & & \\
\hline Achai 7 & & & & & & $\mathrm{C}$ & & & \\
\hline Achai 10 & & & & & & $\mathrm{C}$ & & & \\
\hline Dajal 16 & & & & & & $\mathrm{C}$ & & & \\
\hline Nari Master 14 & & & & & & $\mathrm{C}$ & & & \\
\hline Red Sindhi 2023 & & & & & & $\mathrm{C}$ & & & \\
\hline Red Sindhi 2038 & & & & & & $\mathrm{C}$ & & & \\
\hline Tharparker 1909 & & & & & & $\mathrm{C}$ & & & \\
\hline Sahiwal 1 & & & & & & $\mathrm{C}$ & & & \\
\hline Sahiwal 2 & & & & & & $\mathrm{C}$ & & & \\
\hline Sahiwal 3 & & & & & & $\mathrm{C}$ & & & \\
\hline Dahnni 1 & & & & & & $\mathrm{C}$ & & & \\
\hline Dahnni 2 & & & & & & $\mathrm{C}$ & & & \\
\hline Cholistani 3 & & & & & & & A & & \\
\hline Cholistani 4 & & & & & & & A & & \\
\hline Achai 3 & & & & & & & & & $\mathrm{G}^{*}$ \\
\hline
\end{tabular}

*Change $\mathrm{C} \rightarrow \mathrm{G}$ in Achai 3 produces a change $\mathrm{F} \rightarrow \mathrm{L}$ in the amino acid sequence.

\section{MATERIALS AND METHODS}

Whole blood $(10 \mathrm{~mL})$ was collected from unrelated representative individuals of selected cattle breeds from several breeding areas. The sampling from sibs was deliberately avoided by restricting the number of samples from a given herd (Table I). DNA was extracted from frozen blood after thawing using inorganic extraction method (Babar et al., 2012) and each sample was brought to a concentration of $50 \mathrm{ng} / \mu \mathrm{L}$. Specific primers $\mathrm{mtCytbF}$ 5'-TCCATAAATACAAAGAGCCTTATCAGT-3' and mtCytbR 5'-GCGGCATGGTAATTAAGCTC-3' were designed for cattle Cytochrome $b$ gene (GeneBank Accession No JN817351) using the Primer3 software (v. 0.4.0 ); Rozen and Skaletsky, 2000). The $367 \mathrm{bp}$ of Cyto b was amplified in all samples using $25 \mu \mathrm{L}$ reaction mixture with $2 \mathrm{mM} \mathrm{MgCl} 2,100 \mu \mathrm{M}$ of dNTPs, $0.2 \mu \mathrm{M}$ of each forward and reverse primer and $1 \mathrm{U}$ of Taq DNA polymerase (Fermentas, Thermo Fisher Scientific Inc., USA) was used. The amplification was carried out at an initial denaturation at $94^{\circ} \mathrm{C}$ for $4 \mathrm{~min}, 35$ cycles of denaturation at $94^{\circ} \mathrm{C}$ for $30 \mathrm{~s}$, annealing at $56^{\circ} \mathrm{C}$ for $30 \mathrm{~s}$ and extension at $72^{\circ} \mathrm{C}$ for $45 \mathrm{~s}$ followed by final extension at $72{ }^{\circ} \mathrm{C}$ for $10 \mathrm{~min}$ and cooling at $4^{\circ} \mathrm{C}$ for $1 \mathrm{~h}$. All products were sequenced using an automated sequencer $\mathrm{ABI}$ prism 3130 XL Genetic Analyzer (Applied Biosystems, Inc., Foster City, CA). MEGA software (V 5.05) (Tamura et al., 2011) was used for sequence alignments, translations and phylogenetic analysis.

The numbers of base substitutions per site, averaged over all sequence pairs within and between each group were calculated using the Maximum Composite Likelihood model (Tamura et al., 2004). The analysis involved 152 nucleotide sequences. Codon positions included were $1 \mathrm{st}+2 \mathrm{nd}+3 \mathrm{rd}+$ Noncoding. All positions containing gaps and missing data were eliminated. There were a total of 339 positions in the final dataset. Evolutionary analyses were conducted in MEGA5 software.

Table II.- List of cattle breeds, number (total $=130$ ), species, type and sampling area in Pakistan used in this study.

\begin{tabular}{|c|c|c|c|c|}
\hline Breed & n & Species & Type & Sampling area \\
\hline Sahiwal & 3 & B. p. indicus & Dairy & Punjab \\
\hline Cholistani & 13 & B. p. indicus & Dairy & Punjab \\
\hline Red Sindhi & 17 & B. p. indicus & Dairy & Sindh \\
\hline Tharparker & 23 & B. p. indicus & Dual purpose & Sindh \\
\hline Dhanni & 2 & B. p. indicus & Draught & Punjab \\
\hline Lohani & 16 & B. p. indicus & Draught & Punjab, KPK \\
\hline Dajal & 10 & B. p. indicus & Draught & Punjab \\
\hline Bhangnari & 21 & B. p. indicus & Draught & Balochistan \\
\hline Achai & 12 & B. p. indicus & Draught & KPK \\
\hline Nari Master & 13 & $\begin{array}{l}\text { B. p. indicus } \mathrm{x} \\
\text { B.p.taurus }\end{array}$ & Beef & Balochistan \\
\hline
\end{tabular}




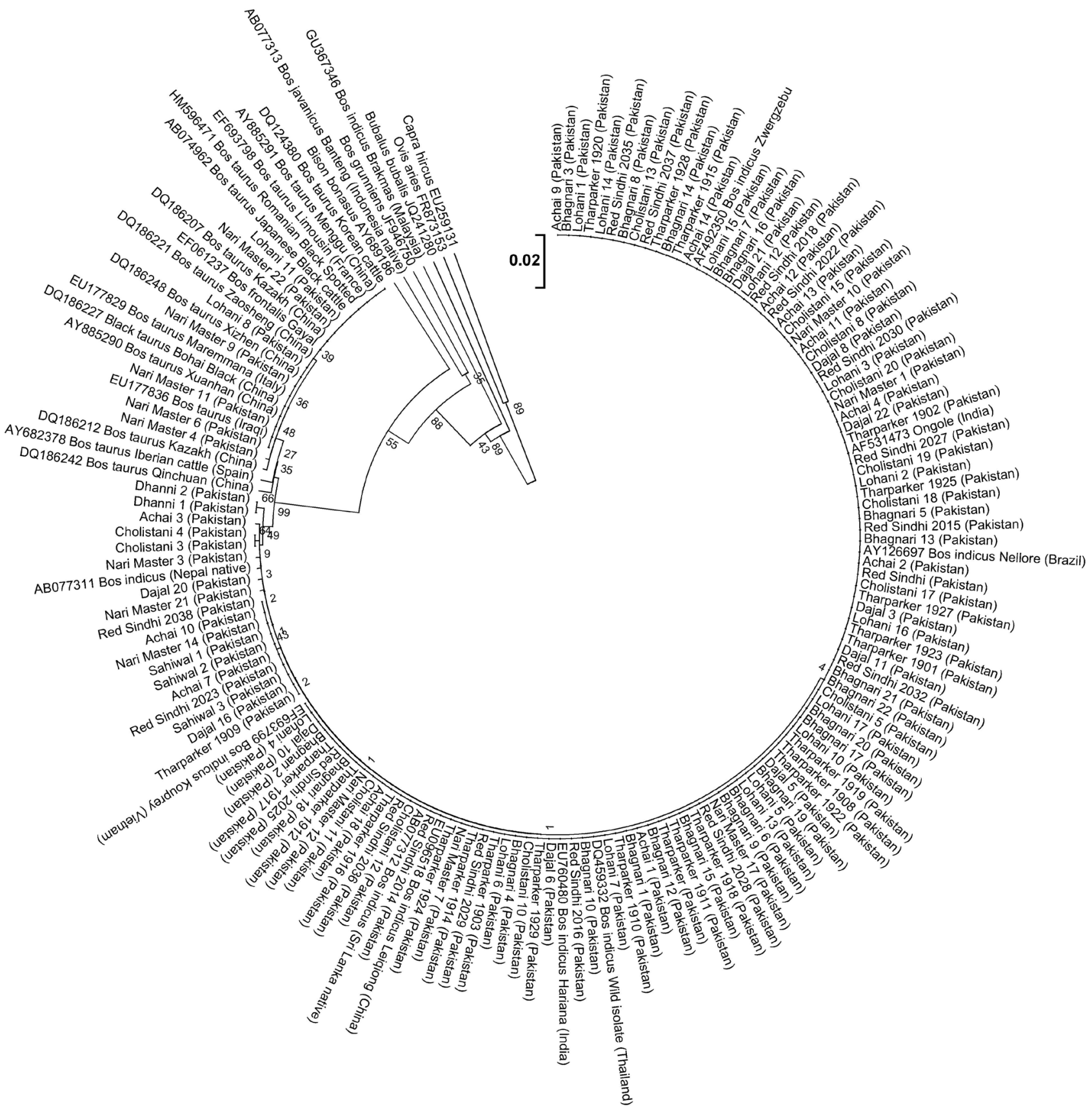

Fig. 1. The phylogenetic tree; using unweighted pair group method with arithmetic mean (UPGMA) showing differentiation between taurine and Indicine cattle, except Lohani and Nari Master.

\section{RESULTS}

Mitochondrial cytochrome b gene sequences (GenBank accession numbers: JN117611 - JN117615 and JX668003 - JX668127) were highly conserved in all the Pakistani cattle (Fig. 1), evidenced by the fact that only 26 of the 130 individuals studied showed nucleotide changes from the consensus sequence (Table II). Nine nucleotide changes were detected in the sequences analyzed, but only changes at 5 positions were present in multiple individuals: one polymorphic site (SNP) was found in nucleotide 318 $(\mathrm{T} \rightarrow \mathrm{C})$ in several breeds of indicine cattle, but not in any of the taurine cattle from GenBank (Fig. 1). The other four changes found in multiple animals of Pakistani cattle, 
are typical of the taurine cattle haplotype, but some were found in two Lohani and five Nari Master Cattle from Pakistan. However, the one animal, Nari Master 3 had only one of the changes found in taurine haplotype, while Nari Master 4 had 3 of the 4 changes. In addition, three changes were present in only one animal and two changes in two animals (Table II). Of all the changes found, only one was a transversion and three (including this transversion) produced amino acid changes in the protein sequence.

The phylogenetic tree built using Unweighted Pair Group Method with Arithmetic Mean (UPGMA) showed a clear differentiation between taurine and indicine cattle (Fig. 1), except for those Pakistani cattle showing mitochondrial taurine sequences. All the indicine cattle showed almost identical sequences. In addition, cattle sequences were significantly different from Bison bonasus, Bos javanicus, Bos grunniens and Bubalus bubalis, as well as the sequences of Ovis aries and Capra hircus. The within breed estimates of divergence were very low in all breeds except for Nari Master (Table III). The estimates of divergence among breeds were also low for most breed pairs, except for Nari Master and Dhanni. However the overall genetic divergence within the $B$. indicus as well as within B. taurus were also very low i.e. 0.002 and 0.003 , respectively, the genetic difference between $B$. indicus and B. taurus was significantly higher i.e. 0.014 .

\section{DISCUSSION}

Domestic cattle are generally considered to be derived from two major subspecies, B. t. taurus and
$B$. $t$. indicus. It is suggested that these two subspecies contributed independently to modern domestic cattle and were domesticated separately 8,000-10,000 years ago (Payne 1991; Loftus et al. 1994). It is also possible that the origin of the Asian cattle is much more complicated; namely, the population may have genes introgressed from other Bovinae species such as B. (Bibos) javanicus, $B$. (Bibos) gaurus or B. (Poephagus) grunniens. Therefore, these species have been suggested as a third source of Asian cattle (Namikawa et al., 1984, 1995; Kawamoto et al., 1992; Kikkawa et al., 1995; Yu et al., 1999; Tu et al., 2000).

It has been previously demonstrated that mitochondrial DNA (mtDNA) haplotypes specific for each subspecies exist in native populations of Asian cattle (Watanabe et al., 1989; Bhat et al., 1990; Kikkawa et al., 1995, 2003; Cai et al., 2007), which agree with our results. Gene flow from taurine cattle into Asian zebu populations has been suggested as an unusual pattern of introgression (Namikawa 1981; Namikawa et al., 1984, 1995; Amano et al., 1994; Kawamoto et al., 1992; Tu et al., 2000; Kikkawa et al., 2003; Cai et al., 2007, 2010). Currently, there is more evidence to show that the origin of the Asian cattle populations include genes introgressed from B. t. taurus and other Bos species (Yu et al., 1999; Tu et al., 2000; Kikkawa et al., 2003; Cai et al., 2010) such as the Bangladesh and Nepali cattle which have mixed breed taurus/indicus mtDNA and SRY genotypes, as well as Indonesian and Nepali cattle showing mixedbred Bali/ indicus and yak/indicus, respectively (Kikkawa et al., 2003).

Table III.- Estimates of evolutionary divergence over sequence pairs between groups. The number of base substitutions per site from averaging over all sequence pairs within each group are shown. The diagonal bold faced numbers show the mean interpopulational evolutionary diversity estimates.

\begin{tabular}{|c|c|c|c|c|c|c|c|c|c|c|c|c|}
\hline & $\begin{array}{c}\text { Other } \\
\text { B. indicus }\end{array}$ & Achai & Bhagnari & Cholistani & Dajal & Lohani & $\begin{array}{c}\text { Nari } \\
\text { Master }\end{array}$ & $\begin{array}{c}\text { Red } \\
\text { Sindhi }\end{array}$ & $\begin{array}{l}\text { Thar- } \\
\text { parker }\end{array}$ & Sahiwal & Dhanni & $\begin{array}{c}\text { Other } \\
\text { B. taurus }\end{array}$ \\
\hline Other $B$. indicus & 0.001 & & & & & & & & & & & \\
\hline Achai & 0.001 & 0.001 & & & & & & & & & & \\
\hline Bhagnari & 0.000 & 0.001 & 0.000 & & & & & & & & & \\
\hline Cholistani & 0.001 & 0.001 & 0.000 & 0.001 & & & & & & & & \\
\hline Dajal & 0.001 & 0.001 & 0.001 & 0.001 & 0.001 & & & & & & & \\
\hline Lohani & 0.002 & 0.002 & 0.001 & 0.002 & 0.002 & 0.003 & & & & & & \\
\hline Nari Master & 0.005 & 0.006 & 0.005 & 0.006 & 0.006 & 0.005 & 0.007 & & & & & \\
\hline Red Sindhi & 0.001 & 0.001 & 0.000 & 0.001 & 0.001 & 0.002 & 0.005 & 0.001 & & & & \\
\hline Tharparker & 0.000 & 0.001 & 0.000 & 0.001 & 0.001 & 0.002 & 0.005 & 0.000 & 0.000 & & & \\
\hline Sahiwal & 0.003 & 0.003 & 0.003 & 0.003 & 0.003 & 0.004 & 0.008 & 0.003 & 0.003 & 0.000 & & \\
\hline Dhanni & 0.006 & 0.006 & 0.006 & 0.006 & 0.006 & 0.007 & 0.011 & 0.006 & 0.006 & 0.003 & 0.000 & \\
\hline Other B. taurus & 0.014 & 0.014 & 0.013 & 0.014 & 0.014 & 0.012 & 0.009 & 0.014 & 0.014 & 0.017 & 0.020 & 0.003 \\
\hline
\end{tabular}


Here we have shown a very distinctive pattern of Cytb gene for each of B. t. taurus and B. t. indicus in the Pakistani breeds. This gene was used to study the genetic differentiation among 18 breeds of cattle from China, successfully identifying taurine, indicine or hybrid origins, and showing a declining south-to-north gradient of female zebu introgression and a geographical hybrid zone of Bos taurus and Bos indicus in China (Cai et al., 2007, 2010). Higher nucleotide diversity in the taurine cattle than in the indicine cattle was found in the Chinese breeds. In addition, Ripamonte et al. (2012) found that the Zebu (Nellore) cattle in Brazil showed large influence of taurine mtDNA. We also found a low degree of introgression from taurine mtDNA into indicine but only in the Lohani breed. This could be caused by the crossbreeding of this breed with taurine cattle, since there is no specific breeding program established for most cattle producers in Pakistan.

It is interesting to see that even though Bison belongs to a different genus, this species and $B$. javanicus were the species phylogenetically closest to taurine/ indicine cattle. This has been reported previously and introgression produced by cattle/bison crossbreeding is suggested as one of the explanation for this result (Cai et al., 2011; Hassanin et al., 2012). In addition, a GenBank sequence reported for indicine cattle from Malaysia (Brakmas breed) was not observed among the indicine cattle analyzed here. This could be due to the reported introgression found in several breeds of cattle from Southeast Asia (Yu et al., 1999; Tu et al., 2000; Kikkawa et al., 2003; Cai et al., 2010). Because native breeds of cattle have been selected for many generations for specific traits and for the resistance to environmental conditions and tolerance to various diseases, they represent a valuable resource for modern cattle production in diverse, non-optimal environments. In order to better use these breeds, this study represent a contribution for their genetic characterization and the cytb gene could be used to detect gene introgression from taurine into indicine cattle, and vice versa.

\section{ACKNOWLEDGEMENTS}

Special thanks to Livestock and Dairy Development Department of Punjab, Khyber Pakhtunkhwa, Balochistan and Livestock and Fisheries Department of Sindh for helping in collection of blood samples from different cattle breeds. The Higher Education Commission of Pakistan is acknowledged for funding (Project No. 20-1703).

\section{Statement of conflict of interest}

Authors have declared no conflict of interest.

\section{REFERENCES}

Amano, T., Miyakoshi, Y., Tokada, T., Kikkawa, T. and Suzuki, M., 1994. Genetic variants of ribosomal DNA and mitochondrial DNA between swamp and river buffaloes. Anim. Genet., 25: 29-36. https:// doi.org/10.1111/j.1365-2052.1994.tb00400.x

Azam, A., Babar, M.E., Firyal, S., Anjum, A.A., Akhtar, N., Asif, M. and Hussain, T., 2012. DNA typing of Pakistani cattle breeds, Tharparkar and Red-Sindhi by microsatellite markers. Mol. Biol. Rep., 39: 845849. https://doi.org/10.1007/s11033-011-0807-1

Bhat, P.P., Mishra, B.P. and Bhat, P.N., 1990. Polymorphism of mitochondrial DNA (mtDNA) in cattle and buffaloes. Biochem. Genet., 28: 311-318. https://doi.org/10.1007/BF02401421

Birungi, J. and Arctander, P., 2001. Molecular systematics and phylogeny of the Reduncini (Artiodactyla: Bovidae) inferred from the analysis of mitochondrial cytochrome $b$ gene sequences. J. Mammal. Evol., 8: 125-147. https://doi. org/10.1023/A:1011369914909

Browers, N., Stauffer J.R. and Kocher, K.D., 1994. Intra and interspecific itochondrial DNA sequence variation within two species of rock-dwelling Cichlids (Teleostei:Cichlidae) from Lake Malawi, Africa. Mol. Phylogenet. Evol., 3: 75-82. https:// doi.org/10.1006/mpev.1994.1009

Cai, X., Chen, H., Lei, C., Wang, S., Xue, K. and Zhang, B., 2007. mtDNA diversity and genetic lineages of eighteen cattle breeds from Bos taurus and Bos indicus in China. Genetica, 131: 175-183. https:// doi.org/10.1007/s10709-006-9129-y

Cai, X., Chen, H. and Lei, C., 2010. Matrilineal genetic inter-introgression of Bos taurus and Bos indicus in China. Livest. Sci., 128: 12-19. https://doi. org/10.1016/j.livsci.2009.06.017

Cai, Y.S., Zhang, L., Shen, F.J., Zhang, W.P., Hou, R., Yue, B.S., Li, J. and Zhang, Z.H., 2011. DNA barcoding of 18 species of Bovidae. Chinese Sci. Bull., 56:164-168. https://doi.org/10.1007/s11434010-4302-1

Carmela, G., Reyes, A., Pesole, G. and Saccone, C., 2000. Lineage-specific evolutionary rate in mammalian mtDNA. Mol. Biol. Evol., 17: 10221031. https://doi.org/10.1093/oxfordjournals. molbev.a026383

GoP, 2017. Economic survey of Pakistan 2016-17. Ministry of Finance, Government of Pakistan, Islamabad.

Hassanin, A., Delsuc, F., Ropiquet, A., Hammer, C., Jansen Van Vuuren, B., Matthee, C., Ruiz- 
Garcia, M., Catzeflis, F., Areskoug, C., Nguyen, T.T. and Couloux, A., 2012. Pattern and timing of diversification of Cetartiodactyla (Mammalia, Laurasiatheria), as revealed by a comprehensive analysis of mitochondrial genomes. C. R. Biol., 335 : 32-50. https://doi.org/10.1016/j.crvi.2011.11.002

Hassanin, A. and Ropiquet, A., 2004. Molecular phylogeny of the tribe Bovini (Bovidae, Bovinae) and the taxonomic status of the Kouprey, Bos sauveli Urbain 1937. Mol. Phylogenet. Evol., 33: 896-907. https://doi.org/10.1016/j.ympev.2004.08.009

Helmer, D., Gourichon, L., Monchot, H., Peters, J. and Sana, S.M., 2005. Identifying early domestic cattle from Pre-Pottery Neolithic sites on the Midddle Euphrates using sexual dimorphism. In: The first steps of animal domestication: New archaeozoological approaches (eds. J.D. Vigne, D. Helmer and J. Peters). Oxbow Books, Oxford, pp. 86-95.

Karthickeyan, S.M.K., Saravanan, R. and Thangaraju, P., 2006. Characterization of Krishna Valley breed of cattle (Bos indicus) in south India using microsatellite markers. Livest. Res. Rural Develop., 18: $11-15$.

Karthickeyan, S.M.K, Sivaselvam, S.N., Selvam R. and Thangaraju, P., 2009. Microsatellite analysis of Kangayam cattle (Bos indicus) of Tamilnadu. Indian J. Sci. Technol., 2: 38-40.

Kawamoto, Y., Namikawa, T., Adachi, A., Amano, T., Shotake, T., Nishida, T., Hayashi, Y., Kattel, B. and Rajubhandary, H.B., 1992. A population genetic study on yak, cattle and their hybrids in Nepal using milk protein variations. Anim. Sci. Tech. (Japan), 63: 563-575. https://doi.org/10.2508/ chikusan.63.563

Kikkawa, Y., Amano, T. and Suzuki, H., 1995. Analysis of genetic diversity of domestic cattle in East and Southwest Asia in terms of variation in restriction sites and sequences of mitochondrial DNA. BioChem. Genet., 33: 51-60. https://doi.org/10.1007/ BF00554558

Kikkawa, Y., Takada, T., Sutopo-Nomura, K., Namikawa, T., Yonekawa, H., and Amano, T., 2003. Phylogenies using mtDNA and SRY provide evidence for male-mediated introgression in Asian domestic cattle. Anim. Genet., 34: 96-101. https:// doi.org/10.1046/j.1365-2052.2003.00956.x

Loftus, R.T., Machugh. D.E., Bradley, D.G., Sharp, P.M. and Cunningham, P., 1994. Evidence for two independent domestication of cattle. Proc. natl. Acad. Sci. USA, 91: 2757-2761. https://doi. org/10.1073/pnas.91.7.2757
Metta, M., Kanginakudru, S., Gudiseva, N. and Nagaraju, J., 2004. Characterization of Indian cattle breeds, Ongole and Deoni (Bos indicus) using microsatellite markers. Genom. Biol. 5: 8-12. https://doi.org/10.1186/gb-2004-5-4-p8

Mukesh, M., Sodhi, M., Bhatia, S. and Mishra, B.P., 2004. Genetic diversity of Indian native cattle breeds as analysed with 20 microsatellite loci. $J$. Anim. Breed. Genet., 121: 416-424. https://doi. org/10.1111/j.1439-0388.2004.00468.x

Namiakwa, T., Masangkay, J.S., Maeda, K.L., Escalada, R.F., Hirunagi, K. and Momongan, V.G., 1995. External characters and karyotypes of the captive tamaraws, Bubalus (B.) mindorensis, at the gene pool in the island of Mindoro, Philippines. $J$. Anim. Genet., 23: 19-28. https://doi.org/10.5924/ abgri1993.23.19

Namikawa, T., 1981. Geographic distribution of bovine hemoglobin- beta $(\mathrm{Hbb})$ alleles and the phylogenetic analysis of the cattle in eastern Asia. Z. Tierzuchtg. Zuchtgsbiol., 98: 151-159. https:// doi.org/10.1111/j.1439-0388.1981.tb00338.x

Namikawa, T., Ito, S. and Amano, T., 1984. Genetic relationship and phylogeny of East and Southeast Asian cattle: Genetic distance and principal component analyses. Z. Zierzucht. Zuchtbiol., 101: 17-32. https://doi.org/10.1111/j.1439-0388.1984. tb00019.x

Nei, M. and Kumar, S., 2000. Molecular evolution and phylogenetics. Oxford University Press, New York.

Payne, W.J.A., 1991. Domestication: A forward step in civilization. In: World animal science (ed. C.G. Hickman). Elsevier, New York, pp. 51-72.

Rehman, M.S. and Khan, M.S., 2009. Genetic diversity of Hariana and Hissar cattle from Pakistan using microsatellite analysis. Pak. Vet. J., 29: 67-71.

Ripamonte, P., Baccaglini, M., Cesar, A.S., Figueiredo, L.G., Balieiro, J.C., Caetano, A.R. and Meirelles, F.V., 2012. Estimation of taurindicine hybridization of American Zebu cattle in Brazil. Genet. Mol. Res., 11: 393-403. https://doi.org/10.4238/2012. February.17.1

Rozen, S. and Skaletskym, H.J., 2000. Primer3 on the WWW for general users and for biologist programmers. In: Bioinformatics methods and protocols: Methods in molecular biology (eds. S. Krawetz and S, Misener). Humana Press, Totowa, NJ, pp. 365-386.

Babar, M.E., Hussain, T., Imran, M., Kumar, S. and Nagarajan, M., 2012. Mitochondrial DNA diversity patterns in Pakistani buffalo. Anim. Genet., 43: $\quad 315-317$. https://doi.org/10.1111/j.1365- 
2052.2011.02250.x

Simon, C., Buckley, T.R., Frati, F., Stewart, J.B. and Beckenbach, A.T., 2006. Incorporating molecular evolution into phylogenetic analysis, and a new compilation of conserved polymerase chain reaction primers for animal mitochondrial DNA. Аnnu. Rev. Ecol. Evol. Syst., 37: 545-579. https://doi. org/10.1146/annurev.ecolsys.37.091305.110018

Sodhi, M., Mukesh, M., Prakash, B., Ahlawat, S.P.S. and Sobti, R.C., 2006. Microsatellite DNA typing for assessment of genetic variability in Tharparkar breed of Indian zebu (Bos indicus) cattle, a major breed of Rajasthan. J. Genet., 85: 165-170. https:// doi.org/10.1007/BF02935326

Tamura, K., Peterson, D., Peterson, N., Stecher, G., Nei, M. and Kumar, S., 2011. MEGA5: Molecular evolutionary genetics analysis using maximum likelihood, evolutionary distance, and maximum parsimony methods. Mol. Biol. Evol., 28: 27312739. https://doi.org/10.1093/molbev/msr121

Tamura, K., Nei, M. and Kumar, S., 2004. Prospects for inferring very large phylogenies by using the neighbor-joining method. Proc. natl. Acad. Sci. USA, 101: 11030-11035. https://doi.org/10.1073/ pnas.0404206101

Troy, C.S., Machugh, D.E., Bailey, J.F., Magee, D.A.,
Loftus, R.T., Cunningham, P., Chamberlain, A.T., Sykes B.C. and Bradley, D.G., 2001. Genetic evidence for Near-Eastern origins of European cattle. Nature, 410: 1088-1091. https://doi. org $/ 10.1038 / 35074088$

Tu, Z.C., Nie, L., Yu, Y., Wen, J.K. and Zhang, Y.P., 2000. Blood protein polymorphism in $B$. frontalis, B. grunniens, B. taurus and B. indicus. Biochem. Genet., 38: 413-416. https://doi. org/10.1023/A:1026484714939

Watanbe, T., Masangkay, J.S., Wakana, S., Saitou, N. and Tomita, T., 1989. Mitochondrial DNA polymorphism in native Philippine cattle based on restriction endonuclease cleavage patterns. Biochem. Genet., 27: 431-438. https://doi. org/10.1007/BF02399672

Yu, Y., Nie, L., He, Z.Q., Wen, J.K., Jian, C.S. and Zhang, Y.P., 1999. Mitochondrial DNA variation in cattle of South China: Origin and introgression. Anim. Genet., 30: 245-250. https://doi.org/10.1046/ j.1365-2052.1999.00483.x

Zardoya, R. and Meyer, A., 1996. Phylogenetic performance mitochondrial protein coding genes in resolving relationship among vertebrate. Mol. Biol. Evol., 13: 933-942. https://doi.org/10.1093/ oxfordjournals.molbev.a025661 